\title{
Molecular Modeling of An Analog Of Curcumin Compounds Pentagamavunon-0 (PGV-0) And Pentagamavunon-1 (PGV-1) Through Computational Chemistry Methods Ab-Initio HF/4-31G
}

\author{
Nurcahyo Iman Prakoso $^{a^{*}}$, Lukman Hakim ${ }^{\text {b }}$, Nuri Hidayati ${ }^{\text {b }}$ \\ ${ }^{\text {a }}$ Program Studi Kimia, Universitas Islam Indonesia, \\ ${ }^{\mathrm{b}}$ Departemen Kimia, Universitas Gadjah Mada \\ *Email : nurcahyo.ip@uii.ac.id
}

\begin{abstract}
ABSTRAK
Kanker payudara merupakan kasus kanker terbanyak kedua di Indonesia, setelah kanker leher rahim. Pertumbuhan sel kanker tersebut dapat dicegah dengan senyawa Pentagamavunon-0 (PGV-0) dan Pentagamavunon-1 (PGV-1). Senyawa tersebut merupakan analog senyawa kurkumin yang memiliki aktivitas sebagai antikanker payudara. Pemodelan struktur senyawa PGV-O dan PGV-1 melalui kimia komputasi dengan metode Ab-Initio HF/4-31G secara teoritis dapat digunakan untuk memprediksi geometri dan spektra elusidasi struktur yang terkait dengan aktivitas farmakologis senyawa tersebut sebagai antikanker.

Penelitian ini meliputi pemodelan struktur dan perhitungan prediksi spektra senyawa PGV-O dan PGV-1 dengan metode kimia komputasi Ab-Initio HF/4-31G, menggunakan perangkat lunak Gaussian03W. Hasil perhitungan dengan menggunakan metode Ab-Initio HF/4-31G selanjutnya dibandingkan dengan data hasil geometri eksperimen serta hasil perhitungan dengan metode semiempiris AMI.

Hasil penelitian menunjukkan bahwa metode kimia komputasi Ab-Initio HF/4$31 G$ memberikan hasil perhitungan yang lebih baik untuk memodelkan struktur senyawa PGV-O dan PGV-1 dibandingkan metode semiempirik AM1.
\end{abstract}

Kata kunci : Kurkumin, PGV-0, PGV-1, Ab-Initio

\begin{abstract}
Breast cancer is the second largest number of cancer cases in Indonesia, after cervical cancer. The growth of these cancer cells can be prevented with compounds Pentagamavunon-O (PGV-O) and Pentagamavunon-1 (PGV-1). This compound is an analog of curcumin compounds that have anti breast cancer activity. Modeling the structure of compound PGV-O and PGV-1 through computational chemistry methods $A b$ initio HF/4-31G could be used to predict the geometry and structure elucidation spectra associated with pharmacological activity such as anticancer compounds theoretically.

This research involves modeling the structures and spectra prediction calculation compounds PGV-O and PGV-1 by computational chemistry methods Ab-initio HF/4-31G, using Gaussian03W. The result using Ab-initio HF/4-31G method then compared with data from experimental geometry and the results of calculations with AM1.

The results showed that computational chemistry methods Ab-initio HF/4-31G calculations give better results for modeling the structure compared semiempirik method AM1.
\end{abstract}

Keywords: Curcumin, PGV-0, PGV-1, Ab-Initio 


\section{Pendahuluan}

Pengobatan

kanker

menggunakan obat herbal yang berasal dari tumbuhan tradhisional untuk saat ini terus dikembangkan. Salah satu obat herbal yang telah dikenal penggunaannya adalah tumbuhan kunir jenis Curcuma longa dan Curcuma xanthorriza, R. Senyawa aktif yang diperoleh dari hasil isolasi tumbuhan kunir tersebut adalah senyawa kurkumin. Berdasarkan berbagai penelitian secara ilmiah telah banyak dilaporkan mengenai aktivitas kurkumin, diantaranya sebagai antioksidan, antiinflamasi, antibakteri, dan antikanker (Sardjiman, 2000).

Struktur kurkumin yang terdiri dari gugus hidroksi fenolik dan gugus $\beta$-diketon, memungkinkan adanya aktivitas sebagai antioksidan, namun gugus metilen yang mengandung hidrogen alfa merupakan gugus yang sangat reaktif sehingga senyawa kurkumin bersifat tidak stabil pada $\mathrm{pH}$ di atas 6,5. Untuk mengatasi kondisi ini, dilakukan modifikasi terhadap senyawa kurkumin untuk memperoleh senyawa yang lebih poten, stabil, aman, efektif, dan memiliki aktivitas yang lebih baik.
Aktivitas farmakologis suatu senyawa obat terkait dengan struktur molekul dari senyawa obat tersebut. Robinson, dkk. (2003) membagi molekul kurkumin menjadi 3 bagian farmakofor yaitu bagian A berupa gugus aromatis, bagian B yaitu ikatan dien-dion dan daerah $\mathrm{C}$ suatu gugus aromatis. Dua gugus aromatis baik simetris maupun tidak simetris menentukaan potensi ikatan antara senyawa obat dengan reseptor.

Senyawa analog kurkumin yang banyak dipelajari aktivitasnya adalah pentagamavunon-0 (PGV-0) dan pentagamavunon-1 (PGV-1). Senyawa tersebut telah diteliti aktivitasnya sebagai antiinflamasi dan ternyata memilki aktivitas yang lebih baik daripada kurkumin (Arief dkk., 2003), namun kompleksitas gugusgugus fungsi senyawa PGV (PGV-0 maupun PGV-1) menyebabkan senyawa PGV memiliki 3 kemungkinan isomer geometri, yaitu struktur E-E, E-Z dan Z-Z. Struktur geometri tersebut berpengaruh pada aktivitas senyawa dan efek sitotoksisitasnya. Analisis menggunakan spektra $X$-ray Diffraction (XRD) yang dilakukan oleh Da'i (2007) menunjukkan bahwa geometri 
struktur PGV-0 dan PGV-1 bersifat<smiles>COc1cc(/C=C/C(=O)CC(=O)/C=C/c2ccc(O)c(OC)c2)ccc1O</smiles>

stabil pada isomer geometri E-E.

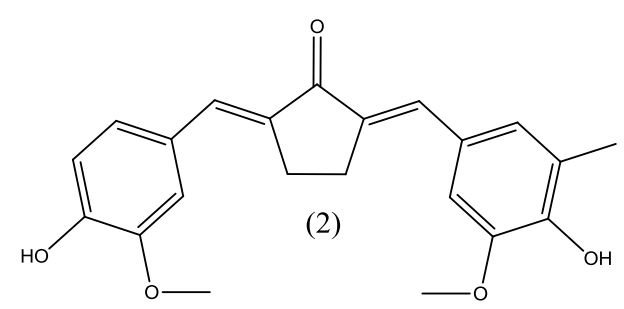<smiles>Cc1cc(/C=C2\CC/C(=C\c3cc(C)c(O)c(C)c3)C2=O)cc(C)c1O</smiles>

Gambar 1. Pembagian gugus kromofor pada Kurkumin (1) (Robinson dkk., 2003) Pentagamavunon-0 (2) dan Pentagamavunon-2 (3) (Da'i, 2007)

Penelitian teoritis dengan semiempiris AM1 dilaporkan oleh pendekatan kimia komputasi penting untuk menentukan kaitan antara struktur PGV-0 dan PGV-1 dengan aktivitas senyawa-senyawa tersebut sebagai anti kanker payudara. Prediksi dan identifikasi struktur molekul melalui kimia komputasi membutuhkan biaya yang relatif lebih murah dibandingkan dengan analisis secara langsung dengan XRD. Untuk mendapatkan kejelasan teoritis tentang aktivitas senyawa PGV-0 dan PGV-1, maka data panjang ikatan dan struktur senyawa teroptimasi harus ditentukan.

Keberhasilan kimia komputasi dalam menjelaskan dan memprediksi struktur geometri senyawa PGV Pranowo dan Hakim (2008) yang membuktikan bahwa struktur geometri PGV-0 dalam keadaan stabil pada posisi E-E. Pada penelitian ini dilakukan pemodelan struktur senyawa analog kurkumin PGV-0 dan PGV-1 secara teoritis melalui kimia komputasi dengan metode mekanika kuantum Ab-Initio HF/6-31(d).

Kebenaran struktur hasil prediksi kimia komputasi ini sangat diperlukan untuk melakukan analisis struktur turunan senyawa PGV-0 dan PGV-1 dalam studi Hubungan Kuantitatif Struktur-aktivitas (HKSA), yaitu dapat memprediksi senyawa baru yang memiliki aktivitas lebih tinggi dengan metode kimia komputasi 
dibandingkan dengan PGV-0 dan PGV-1.

Kemutahiran penelitian ini terletak pada penggunaan metode kimia komputasi dalam memprediksi struktur, sifat dan aktivitas dari suatu senyawa, meskipun senyawa tersebut belum pernah disintesis sekalipun. Metode Ab Initio secara teoritis dapat memodelkan senyawa lebih baik daripada metode semiempirik. Oleh karena itu, diharapkan dengan menggunakan metode $A b$ Initio dapat memodelkan senyawa PGV-0 dan PGV-1 dengan lebih baik sehingga dapat digunakan sebagai acuan dalam pengembangan senyawa analog kurkumin dengan aktivitas antikanker yang lebih baik, aman dan efektif.

Tujuan dari penelitian ini adalah untuk mengetahui metode kimia komputasi yang sesuai untuk pemodelan struktur senyawa PGV-0 dan PGV-1 dengan cara membandingkan spektra elusidasi struktur X-Ray Difraction (XRD) hasil analisis eksperimen dengan data geometri hasil perhitungan menggunakan metode kimia komputasi sehingga dapat diketahui struktur, sifat dan aktivitas senyawa PGV-0 dan PGV-1.

\section{Metode Penelitian}

\subsection{Bahan}

Pada penelitian ini digunakan data jarak antara atom dari data X-Ray Difraction (XRD), spektra ${ }^{1} \mathrm{H}-\mathrm{NMR}$ dan ${ }^{13} \mathrm{C}$-NMR eksperimen yang telah diteliti olah Da'i (2007) dari senyawa analog kurkumin PGV-0 dan PGV-1.

\subsection{Peralatan}

Peralatan yang digunakan dalam penelitian ini adalah perangkat keras berupa komputer Pentium IV 2,4 GHz dengan RAM 256 MB. Perangkat lunak kimia komputasi yaitu Gaussview 3.07 dan Gaussian03W (Revision-C.01).

\subsection{Prosedur}

Optimasi Geometri

Dibuat struktur awal 3D dengan program visualisasi molekul Gaussview 3.07, proses dilanjutkan dengan optimasi geometri struktur berupa minimalisasi energi struktur untuk memperoleh konformasi struktur terstabil menggunakan program Gaussian03. Metode yang digunakan adalah metode Ab-Initio pada tingkat teori Hatree-Fock dengan basis set 4-31G (HF/4-31G). Hasil geometri dibandingkan dengan XRD 
eksperimen, dan hasil perhitungan semiempiris AM1 yang telah dilakukan pada penelitian sebelumnya.

Perhitungan Gelombang

Spektra ${ }^{1} \mathrm{H}$-NMR dan ${ }^{13} \mathrm{C}-\mathrm{NMR}$

Struktur hasil optimasi

dilanjutkan dengan perhitungan pergeseran kimia NMR. Untuk pergeseran kimia pada spektra ${ }^{1} \mathrm{HNMR}$ dan ${ }^{13} \mathrm{CNMR}$ digunakan metode Gauge-Independent Atomic Orbital (GIAO) pada tingkat teori HF/6-31G. Data hasil perhitungan berupa nilai pergeseran absolut (Absolute Shielding) dari setiap masing atom, kemudian data diolah kembali menggunakan program Facio 11.8.4 sehingga didipatkan pergeseran kimia dari masing-masing atom kemudian dibandingkan dengan spektra hasil eksperimen.
Hasil yang lebih mendekati XRD eksperimen menunjukan metode yang lebih baik.

\section{Hasil dan Pembahasan}

\subsection{Struktur Molekul PGV-o dan PGV-1}

Struktur geometri suatu senyawa berbentuk kristalin dapat diidentifikasi melalui analisis dengan metode XRD. Metode XRD didasarkan pada nilai koordinat masing-masing atom penyusun suatu senyawa. Koordinat atom-atom tersebut bersifat spesifik dan tertentu, sehingga memiliki nilai yang berbeda untuk masing-masing atom. Panjang ikatan, jarak antar atom dan sudut ikatan yang terbentuk dalam suatu senyawa dapat ditentukan berdasarkan koordinat atom-atom tersebut.

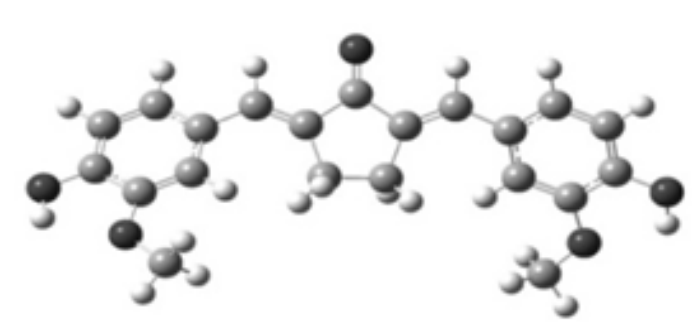

(a)

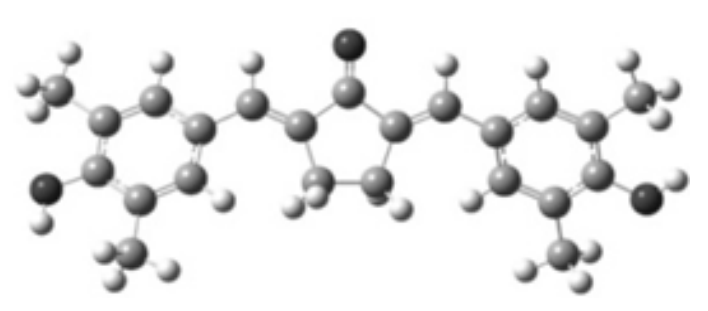

(b)

Gambar 2 Struktur 3 dimensi (a) PGV-0 dan (b) PGV-1 hasil optimasi 
Tabel 1. Jarak antar atom PGV-0 hasil eksperimen dengan hasil perhitungan kimia komputasi (dalam satuan $\AA$ )

\begin{tabular}{|c|c|c|c|c|c|}
\hline \multirow{2}{*}{ Atom (Gugus) } & \multirow{2}{*}{$\frac{\text { Eksperimen }}{\mathrm{R}}$} & \multicolumn{2}{|c|}{ AM1 } & \multicolumn{2}{|c|}{$\mathrm{HF} / 4-31 \mathrm{G}$} \\
\hline & & $\mathrm{R}$ & $\Delta$ & $\mathrm{R}$ & $\Delta$ \\
\hline $\mathrm{C} 1--\mathrm{O} 1(\mathrm{C}=\mathrm{O})$ & 1,225 & 1,233 & $-0,008$ & 1,221 & 0,004 \\
\hline $\begin{array}{c}\mathrm{C} 2 / 5---\mathrm{C} 3 / 4 \\
\text { (siklopentanon) }\end{array}$ & 1,502 & 1,493 & 0,009 & 1,510 & $-0,008$ \\
\hline $\begin{array}{c}\mathrm{C} 1--\mathrm{C} 2 / 5 \\
\text { (siklopentanon) }\end{array}$ & 1,470 & 1,488 & $-0,018$ & 1,479 & $-0,009$ \\
\hline $\mathrm{C} 7^{1}---\mathrm{C} 2 / 5$ & 1,347 & 1,341 & 0,006 & 1,329 & 0,018 \\
\hline $\mathrm{C} 1^{1}--\mathrm{C}^{1}$ & 1,447 & 1,452 & $-0,005$ & 1,464 & $-0,017$ \\
\hline $\mathrm{H}^{\mathrm{I}}---\mathrm{H} 7^{\mathrm{I}}$ & 2,367 & 2,435 & $-0,068$ & 2,368 & $-0,001$ \\
\hline $\mathrm{H} 2^{1}---\mathrm{H}\left(-\mathrm{OCH}_{3}\right)$ & 2,392 & 2,442 & $-0,05$ & 2,441 & $-0,049$ \\
\hline $\mathrm{H} 2^{1}---\mathrm{H} 3 / 4$ & $2,085 /$ & $2,096 /$ & $-0,011 /$ & $2,342 /$ & $-0,257 /$ \\
\hline $\mathrm{H} 7^{1}---\mathrm{H} 3 / 4$ & $\begin{array}{l}2,262 \\
4,196\end{array}$ & $\begin{array}{l}2,529 \\
3,993\end{array}$ & $\begin{array}{l}0,267 \\
0,203\end{array}$ & $\begin{array}{l}2,368 \\
3,983\end{array}$ & $\begin{array}{c}-0,106 \\
0,213\end{array}$ \\
\hline
\end{tabular}

Tabel 2. Jarak antar atom PGV-1 hasil eksperimen dengan hasil perhitungan kimia komputasi (dalam satuan $\AA$ )

\begin{tabular}{|c|c|c|c|c|c|}
\hline \multirow{2}{*}{ Atom (Gugus) } & Eksperimen & \multicolumn{2}{|c|}{ AM1 } & \multicolumn{2}{|c|}{$\mathrm{HF} / 4-31 \mathrm{G}$} \\
\hline & $\mathrm{R}$ & $\mathrm{R}$ & $\Delta$ & $\mathrm{R}$ & $\Delta$ \\
\hline C1---O1 $(\mathrm{C}=\mathrm{O})$ & 1,238 & 1,234 & 0,004 & 1,222 & 0,016 \\
\hline $\begin{array}{c}\mathrm{C} 2 / 5---\mathrm{C} 3 / 4 \\
\text { (siklopentanon) }\end{array}$ & 1,512 & 1,492 & 0,02 & 1,510 & 0,002 \\
\hline $\begin{array}{c}\mathrm{C} 1---\mathrm{C} 2 / 5 \\
\text { (siklopentanon) }\end{array}$ & 1,480 & 1,487 & $-0,007$ & 1,479 & 0,001 \\
\hline $\mathrm{C} 7^{1}---\mathrm{C} 2 / 5$ & 1,335 & 1,341 & $-0,006$ & 1,329 & 0,006 \\
\hline $\mathrm{C} 1^{1}---\mathrm{C} 7^{1}$ & 1,468 & 1,451 & 0,017 & 1,465 & 0,003 \\
\hline $\mathrm{H} 6^{1}---H 7^{1}$ & 2,353 & 2,402 & $-0,049$ & 2,354 & $-0,001$ \\
\hline $\mathrm{H} 2^{1}---\mathrm{H}\left(-\mathrm{CH}_{3}\right) 9^{1}$ & $\begin{array}{r}2,474 / \\
2,434\end{array}$ & $\begin{array}{c}2,347 / \\
2,307\end{array}$ & $\begin{array}{c}0,127 / \\
0,127\end{array}$ & $\begin{array}{r}2,328 / \\
2,350\end{array}$ & $\begin{array}{r}0,146 / \\
0,084\end{array}$ \\
\hline $\mathrm{H} 6^{1}---\mathrm{H}\left(-\mathrm{CH}_{3}\right) 8^{1}$ & 2,329 & 2,355 & $-0,026$ & 2,342 & $-0,013$ \\
\hline $\mathrm{H} 2^{1}---\mathrm{H} 3 / 4$ & $\begin{array}{r}2,321 / \\
2,074\end{array}$ & $\begin{array}{r}2,469 / \\
2,090\end{array}$ & $\begin{array}{l}-0,148 / \\
-0,016\end{array}$ & $\begin{array}{c}2,342 / 2, \\
342\end{array}$ & $\begin{array}{l}-0,021 / \\
-0,268\end{array}$ \\
\hline H7 ${ }^{1}---H 3 / 4$ & 4,018 & 3,990 & 0,028 & 3,977 & 0,041 \\
\hline
\end{tabular}

Perhitungan dengan metode Ab-Initio $\mathrm{HF} / 4-31 \mathrm{G}$ memberikan data jarak antar atom dalam PGV-0 (Tabel 1) dan dalam PGV-1 (Tabel 2). Hasil perhitungan tersebut dibandingkan dengan data hasil eksperimen dan data hasil analisis dengan metode semiempiris AM1 yang telah dilakukan oleh penulis sebelumnya.

Analisis yang dilakukan terhadap jarak antar atom pada struktur PGV-0 menggunakan metode Ab-Initio HF/4-31G tidak menunjukkan perbedaan yang signifikan dengan hasil eksperimen. Pada senyawa PGV-0, jarak antar atom yang dihubungkan oleh ikatan rangkap dua cenderung lebih kecil daripada jarak pada ikatan tunggal, hal ini diperkuat dengan data yang diperoleh dari hasil eksperimen. 
Berdasarkan Tabel 1, secara umum metode Ab-Initio $\mathrm{HF} / 4-31 \mathrm{G}$ memberikan hasil yang lebih mendekati nilai eksperimen daripada metode semiempiris AM1. Penggunaan metode Ab-Initio HF/4$31 \mathrm{G}$ untuk analisis dan prediksi jarak antar atom dalam PGV-1 juga memberikan hasil yang hampir sama, seperti tercantum pada Tabel 2, yang menunjukkan bahwa jarak antar atom hasil prediksi metode Ab-Initio $\mathrm{HF} / 4$ $31 \mathrm{G}$ lebih mendekati nilai eksperimen.

Sudut ikatan pada senyawa PGV-0 dan PGV-1 menggunakan metode Ab-Initio $\mathrm{HF} / 4-31 \mathrm{G}$ ditunjukkan pada Tabel 3 (PGV-0) dan Tabel 4 (PGV-1). Sudut ikatan antara atom-atom penyusun senyawa $\mathrm{PGV}-0$ dan PGV-1 hasil analisis dengan metode Ab-Initio HF/4-31G menunjukkan perbedaan yang relatif tidak signifikan dengan hasil eksperimen. Sudut terbesar pada senyawa PGV-0 dibentuk oleh atom C7 ${ }^{1}-\mathrm{C} 2 / 5-\mathrm{C} 3 / 4$ yaitu $131,22^{0}$ pada $A b$ Initio $\mathrm{HF} / 4-31 \mathrm{G}$ dan $129,17^{0}$ pada AM1, sedangkan pada senyawa PGV1 sudut terbesar dibentuk oleh atom $C 7^{1}-\mathrm{C} 2 / 5-\mathrm{C} 3 / 4$ yaitu sebesar $131,22^{0}$ pada Ab-Initio HF/4-31G dan $129,32^{0}$ pada AM1.
Sudut ikatan berbeda secara signifikan pada atom-atom di sekitar ikatan rangkap. Besarnya sudut tersebut menunjukkan bahwa gugus siklopentanon cenderung mempertahankan sudut ikatannya dan adanya gugus aromatis yang memiliki struktur kaya elektron memperbesar sudut ikatan yang menghubungkan gugus inti aromatis terminal dengan siklopentanon. Secara umum, data ikatan-ikatan tersebut membuktikan bahwa PGV-0 merupakan struktur yang kaku dengan adanya gugus siklopentanon (Dai, 2007).

Berbeda dengan metode $A b$ Initio $\mathrm{HF} / 4-31 \mathrm{G}$, metode semiempiris AM1 menunjukkan perbedaan yang cukup besar $\left(\Delta=3,15^{\circ}\right)$ pada sudut ikat $\left(\mathrm{C} 1^{1}-\mathrm{C} 7^{1}-\mathrm{C} 2 / 5\right)$ dibandingkan selisih sudut ikat hasil perhitungan $A b$ Initio $\mathrm{HF} / 4-31 \mathrm{G}$, sehingga metode $A b$ Initio $\mathrm{HF} / 4-31 \mathrm{G}$ mampu menggambarkan dengan baik besar sudut ikatan pada PGV-0 dan PGV-1 mendekati hasil eksperimen. 
Tabel 3. Sudut ikat PGV-0 hasil eksperimen dengan hasil perhitungan kimia komputasi (dalam satuan ${ }^{0}$ )

\begin{tabular}{|c|c|c|c|c|c|}
\hline \multirow{2}{*}{ Ikatan } & Eksperimen & \multicolumn{2}{|c|}{ AM1 } & \multicolumn{2}{c|}{ HF/4-31G } \\
\cline { 2 - 5 } & $\mathrm{L}$ & $\mathrm{L}$ & $\Delta$ & $\mathrm{L}$ & $\Delta$ \\
\hline $\mathrm{C} 1$-C2/5-C7 & 117,92 & 122,11 & $-4,19$ & 120,24 & $-2,32$ \\
\cline { 1 - 1 } $\mathrm{C}^{1}-\mathrm{C} 2 / 5-\mathrm{C} 3 / 4$ & 131,72 & 129,17 & 2,55 & 131,22 & 0,5 \\
\cline { 1 - 1 } C1 $^{1}-\mathrm{C} 7^{1}-\mathrm{C} 2 / 5$ & 131,50 & 127,78 & 3,72 & 130,08 & 1,42 \\
\cline { 1 - 1 } $\mathrm{C} 1-\mathrm{C} 2 / 5-\mathrm{C} 3 / 4$ & 110,39 & 108,67 & 1,72 & 108,50 & 1,89 \\
\hline
\end{tabular}

Tabel 4. Sudut ikat PGV-1 hasil eksperimen dengan hasil perhitungan kimia komputasi (dalam satuan ${ }^{0}$ )

\begin{tabular}{|c|c|c|c|c|c|}
\hline \multirow{2}{*}{ Ikatan } & Eksperimen & \multicolumn{2}{|c|}{ AM1 } & \multicolumn{2}{|c|}{$\mathrm{HF} / 4-31 \mathrm{G}$} \\
\hline & $\mathrm{L}$ & $\mathrm{L}$ & $\Delta$ & $\mathrm{L}$ & $\Delta$ \\
\hline $\mathrm{C} 1-\mathrm{C} 2 / 5-\mathrm{C} 7^{1}$ & 120,93 & 121,99 & $-1,06$ & 120,15 & 0,78 \\
\hline $\mathrm{C} 7^{1}-\mathrm{C} 2 / 5-\mathrm{C} 3 / 4$ & 130,14 & 129,32 & 0,82 & 131,24 & $-1,10$ \\
\hline $\mathrm{C} 1^{1}-\mathrm{C} 7^{1}-\mathrm{C} 2 / 5$ & 131,25 & 128,10 & 3,15 & 130,10 & 1,15 \\
\hline $\mathrm{C} 1-\mathrm{C} 2 / 5-\mathrm{C} 3 / 4$ & 109,81 & 108,66 & 1,15 & 108,57 & 1,24 \\
\hline
\end{tabular}

\subsection{Spektra NMR}

Penentuan struktur senyawa PGV-0 dan PGV-1 dapat dilakukan dengan menggunakan spektroskopi ${ }^{1} \mathrm{H}-\mathrm{NMR}$ dan ${ }^{13} \mathrm{C}-\mathrm{NMR}$. Kedua spektra yang dihasilkan dapat digunakan untuk menentukan ikatan antara karbon dengan hidrogen dalam struktur PGV-0 dan PGV-1. Spektra ${ }^{1} \mathrm{H}-\mathrm{NMR}$ menunjukkan pergeseran kimia $(\delta)$ untuk atom-atom tertentu. Pada tahap ini, digunakan metode $A b$ Initio $\mathrm{HF} / 4-31 \mathrm{G} / \mathrm{HF} / 6-31 \mathrm{G}$ yang dibandingkan dengan hasil eksperimen penelitian yang dilakukan oleh Dai (2007).

Gugus-gugus yang terdapat dalam senyawa PGV-0 dan PGV-1 mempengaruhi besarnya pergeseran kimia yang dialami oleh atom-atom tertentu dalam senyawa. Pada dasarnya senyawa PGV-0 dan PGV-1 terdiri dari gugus aromatis benzena, gugus pentanon dan hidroksi yang terikat pada cincin benzena. Perbedaan antara struktur senyawa PGV-0 dengan PGV-1 terletak pada gugus alkil yang terikat pada posisi atom $\mathrm{C} 3^{1}$ dan $\mathrm{C}^{1}$. Pada PGV-0, gugus yang terikat $\mathrm{C}^{1}$ adalah metoksi $\left(\mathrm{OCH}_{3}\right)$, sedangkan pada PGV-1 adalah metil $\left(\mathrm{CH}_{3}\right)$. Gugus yang terikat pada atom $\mathrm{C}^{1}$ dalam PGV-0 berupa hidrogen (H), sedangkan dalam PGV-1 adalah metil $\left(\mathrm{CH}_{3}\right)$. 

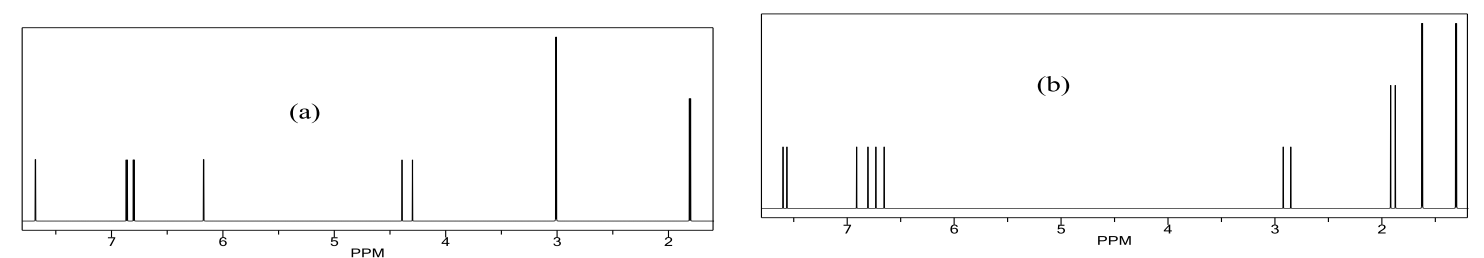

Gambar 4. Spektra ${ }^{1} \mathrm{H}-\mathrm{NMR}$ (a) PGV-0 dan (b) PGV-1 hasil perhitungan $A b$ Initio $\mathrm{HF} / 4-31 \mathrm{G} / / \mathrm{HF} / 6-31 \mathrm{G}$

Tabel 5. Pergeseran kimia H-NMR $\left(\delta_{\mathrm{H}}\right)$ senyawa PGV-0 dan PGV-1 hasil eksperimen dengan hasil perhitungan kimia komputasi (dalam satuan ppm)

\begin{tabular}{|c|c|c|c|c|c|c|}
\hline \multirow[b]{2}{*}{ Atom } & \multicolumn{3}{|c|}{ PGV-0 } & \multicolumn{3}{|c|}{ PGV-1 } \\
\hline & Eksperimen & $\begin{array}{c}\mathrm{HF} / 4-31 \mathrm{G} / / \\
\mathrm{HF} / 6-31 \mathrm{G}\end{array}$ & $\Delta$ & Eksperimen & $\begin{array}{c}\mathrm{HF} / 4-31 \mathrm{G} / / \\
\mathrm{HF} / 6-31 \mathrm{G}\end{array}$ & $\Delta$ \\
\hline 3,4 & 3,06 & 1,81 & 1,25 & 2,99 & 1,92 & 1,07 \\
\hline $2^{1}$ & 7,24 & 6,17 & 1,07 & 7,26 & 6,91 & 0,35 \\
\hline $5^{1}$ & 6,90 & 6,86 & 0,04 & - & - & - \\
\hline $6^{1}$ & 7,14 & 6,8 & 0,34 & 7,26 & 6,81 & 0,45 \\
\hline $7^{1}$ & 7,37 & 7,68 & $-0,31$ & 7,26 & 7,56 & $-0,3$ \\
\hline $8^{1}\left(\mathrm{CH}_{3}\right)$ & - & - & - & 2,21 & 1,63 & 0,58 \\
\hline$-\mathrm{OH}$ & 9,70 & 4,39 & 5,31 & 8,90 & 2,92 & 5,98 \\
\hline$-\mathrm{OCH}_{3}$ & 3,84 & 3,01 & 0,83 & - & - & - \\
\hline
\end{tabular}

Pergeseran kimia hasil

perhitungan komputasi, baik untuk senyawa PGV-0 maupun PGV-1, tidak menunjukkan perbedaan yang signifikan dengan pergeseran kimia hasil eksperimen. Kemiripan nilai pergeseran kimia tersebut menunjukkan keakuratan metode $A b$ Initio $\mathrm{HF} / 431 \mathrm{G} / / \mathrm{HF} / 6-31 \mathrm{G}$ dalam memprediksi spektra H-NMR teoritis senyawa PGV-0 dan PGV-1.

Pada eksperimen analisis senyawa dengan menggunakan spektra H-NMR dibutuhkan pelarut dimetil sulfoksida (DMSO), sedangkan pada perhitungan komputasi, analisis dilakukan dengan asumsi senyawa

berada dalam fasa gas tanpa memperhitungkan faktor pelarut. Hal ini menyebabkan perbedaan yang cukup signifikan pada pergeseran kimia gugus hidroksi (OH). Hasil eksperimen menunjukkan pergeseran kimia $\mathrm{OH}$ pada 9,70 ppm untuk PGV0 dan 8,90 ppm untuk PGV-1, sedangkan pada hasil perhitungan komputasi menunjukkan pergeseran kimia yang jauh berbeda yaitu pada 4,39 ppm dan 2,92 ppm. Perbedaan tersebut terjadi karena dimungkinkan terbentuk ikatan hidrogen antar atom oksigen pada $\mathrm{OH}$ dengan atom hidrogen senyawa pelarut. 
Analisis dengan ${ }^{13} \mathrm{C}-\mathrm{NMR}$ untuk senyawa PGV-0 dan PGV-1 menghasilkan pergeseran kimia $\delta c$ yang bervariasi seperti disajikan pada gambar 5 dan tabel 6. Pergeseran kimia $\delta \mathrm{c}$ terbesar ditemukan pada posisi atom C1 yaitu sebesar 194,80 ppm untuk PGV-0 dan 194,81 ppm untuk PGV-1 sesuai hasil eksperimen, sedangkan analisis dengan metode $A b$ Initio $\mathrm{HF} / 4-31 \mathrm{G} / / \mathrm{HF} / 6-31 \mathrm{G}$ sebesar 201,67 ppm untuk PGV-0 dan 202,24 ppm untuk PGV-1. Spektra untuk pergeseran kimia $\delta$ c gugus keton $\mathrm{C}=\mathrm{O}$ menghasilkan spektra yang terletak paling kiri karena atom $\mathrm{C}$ pada gugus keton bersifat paling tidak terlindungi.
Pergeseran kimia terkecil ditemukan pada atom $\mathrm{C} 3,4$ yaitu sebesar 25,90 ppm untuk PGV-0 dan 25,94 ppm untuk PGV-0. Hasil perhitungan dengan metode Ab-Initio HF/4-31G//HF/6-31G ternyata menghasilkan pergeseran kimia yang sedikit berbeda dengan hasil eksperimen, yaitu 20,64 ppm untuk PGV-0 dan 20,76 ppm untuk PGV1. Secara umum dapat disimpulkan bahwa metode Ab-Initio HF/431G//HF/6-31G mampu menggambarkan spektra ${ }^{1} \mathrm{H}-\mathrm{NMR}$ dan ${ }^{13} \mathrm{C}-\mathrm{NMR}$ dengan cukup baik dan akurat.

Tabel 6. Pergeseran kimia ${ }^{13} \mathrm{C}-\mathrm{NMR}\left(\delta_{\mathrm{C}}\right)$ senyawa PGV-0 dan PGV-1 hasil eksperimen dengan hasil perhitungan kimia komputasi (dalam satuan ppm)

\begin{tabular}{|c|c|c|c|c|c|c|}
\hline \multirow[b]{2}{*}{ Atom } & \multicolumn{3}{|c|}{ PGV-0 } & \multicolumn{3}{|c|}{ PGV-1 } \\
\hline & Eksperimen & $\begin{array}{c}\mathrm{HF} / 4-31 \mathrm{G} / / \\
\mathrm{HF} / 4-31 \mathrm{G}\end{array}$ & $\Delta$ & Eksperimen & $\begin{array}{c}\mathrm{HF} / 4-31 \mathrm{G} / / \\
\mathrm{HF} / 4-31 \mathrm{G}\end{array}$ & $\Delta$ \\
\hline 1 & 194,80 & 201,67 & $-6,87$ & 194,81 & 202,24 & $-7,43$ \\
\hline 2,5 & 132,82 & 127,43 & 5,39 & 132,56 & 128,04 & 4,52 \\
\hline 3,4 & 25,90 & 20,64 & 5,26 & 25,94 & 20,76 & 5,18 \\
\hline $1^{1}$ & 127,16 & 124,8 & 2,36 & 126,72 & 125,54 & 1,18 \\
\hline $2^{1}$ & 114,50 & 109,34 & 5,16 & 131,41 & 128,65 & 2,76 \\
\hline $3^{1}$ & 147,69 & 139,95 & 7,74 & 124,62 & 123,49 & 1,13 \\
\hline $4^{1}$ & 134,22 & 143,54 & $-9,32$ & 155,14 & 148,58 & 6,56 \\
\hline $5^{1}$ & 124,76 & 115,28 & 9,48 & 124,62 & 124,02 & 0,6 \\
\hline $6^{1}$ & 115,89 & 127,17 & $-11,28$ & 131,41 & 131,72 & $-0,31$ \\
\hline $7^{1}$ & 148,50 & 134,16 & 14,34 & 134,54 & 133,72 & 0,81 \\
\hline$-\mathrm{OCH}_{3}$ & 55,56 & 44,72 & 10,84 & - & - & - \\
\hline
\end{tabular}



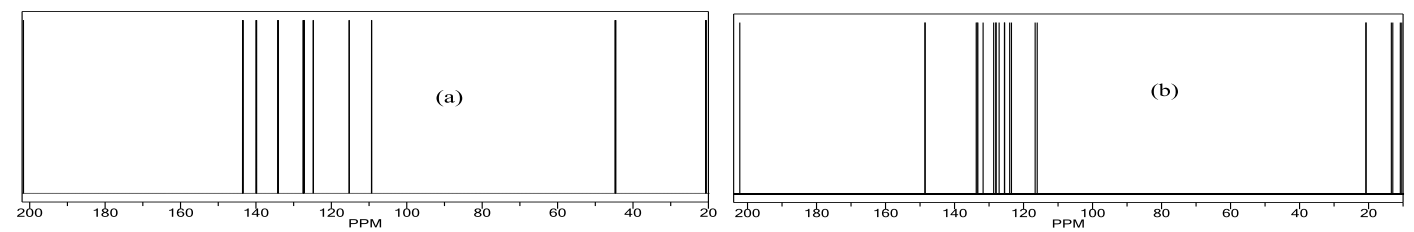

Gambar 5. Spektra ${ }^{13}$ C-NMR (a) PGV-0 dan (b) PGV-1 hasil perhitungan $A b$ Initio $\mathrm{HF} / 4-31 \mathrm{G} / / \mathrm{HF} / 6-31 \mathrm{G}$

\section{Kesimpulan}

Metode Ab-Initio HF/4-31G

dapat digunakan memodelkan struktur geometri senyawa PGV-0 dan PGV-1 lebih baik dibandingkan metode semiempiris AM1 yang telah dilakukan sebelumnya. Metode $A b$ Initio $\mathrm{HF} / 4-31 \mathrm{G}$ juga dapat digunakan untuk memprediksi spektra NMR teoritis dari senyawa PGV-0 dan PGV1 dengan cukup baik. Berdasarkan kajian tersebut diharapkan metode $A b$ Initio $\mathrm{HF} / 4-31 \mathrm{G}$ dapat digunakan sebagai acuan dalam pengembangan senyawa analog kurkumin lain dengan aktivitas antikanker yang lebih baik, aman dan efektif.

\section{Daftar Pustaka}

Arief R. H., Lukman H., Supardjan A.M., 2003. Majalah Farmasi Indonesia, 14 (1), $244-249$.

Da'i, M., 2007. Mekanisme Molekular Aktivitas Analog Kurkumin Pentagamavunon Terhadap Sel Kanker Payudara (T47D), Disertasi, Sekolah Pasca Sarjana, Universitas Gadjah Mada, Yogyakarta.
Julianus, J., 2006. Sintesis dan Uji Aktivitas Diasetil Pentagamavunon-1, Tesis, Sekolah Pasca Sarjana, Universitas Gadjah Mada, Yogyakarta.

Klauber-DeMore, N., Zee, K.J.V., Linkov, I., Borgen, P.I., Gerald, W.L., 2001. Clin. Cancer Res., 7, 2434-2439

Leach, A.R., 2001. Molecular Modeling: Principles and Application, Second edition, Harlow : Pearson Education Limited.

Pranowo, H.D, dan Hakim, L., 2008. Structure Modeling of Curcumin Derivative Compounds Pentagamavunon (PGV) by Using Semiempirical Method, Seminar Nasional Kimia XVII, Jurusan Kimia, Universitas Gadjah Mada, Yogyakarta, 19 Juli 2008.

Robinson, T.P., Ehler, T., Hubbard, R.B., Iv, Bai, X., Arbiser J.L., Goldsmith D.J., and Bowen J.P., 2003. Desain, Synthesis Amd Biological Evaluation of Angiogenesis Inhibitor: Aromatic Enone and Dienone Analogues of Curcumin, Bioor. Med. Chem. Lett., 13, 115117.

Sardjiman, 2000. Synthesis of Some New Series of Curcumin Analogues, Antioxydative, 
Antiinflammatory,

Antibacterial Activities, and Qualitative -Structure Activity Relationships, Disertasi, Universitas Gadjah Mada, Yogyakarta.

Supriyadi, 2006. Brominasi 2,5-bis( $4^{1}$ hidroksi-3 ${ }^{1}$-metoksibenziliden) siklopentanon dan Indentifikasinya secara Spektroskopi, Tesis, Sekolah Pasca Sarjana, Universitas Gadjah Mada, Yogyakarta.
Tjindarbumi, D., dan Mangunkusumo, R., 2002. Cancer in Indonesia, Present dan Future, Jpn. J. Clin. Oncol., 32 (Supplement 1), S17-S21.

Wijaya, K, Tahir, I., dan Pranowo, 2003. Study of Double Protons Migration Mechanism in Supramolecular Sructures of Acetic Acid-Water and AceticAcid Acid-Ammonia By AbInitio Method., Indo. J. Chem., 3

(2),

102-110. 